Mediers påverkan

Förskolebarns hälsa och föräldrarnas roll vid denna påverkan

En literaturstudie 

U nordon 



\title{
Mediers påverkan på förskole- barns hälsa och föräldrarnas roll vid denna påverkan
}

\author{
En litteraturstudie
}

G. Sandstig, B. Johansson och K.C. Ringsberg

(Red. K.C. Ringsberg).

TemaNord 2013:502 
Mediers påverkan på förskolebarns hälsa och föräldrarnas roll vid denna påverkan

En litteraturstudie

G. Sandstig, B. Johansson och K.C. Ringsberg (Red. K.C. Ringsberg)

ISBN 978-92-893-2460-1

http://dx.doi.org/10.6027/TN2013-502

TemaNord 2013:502

(C) Nordiska ministerrådet 2013

Layout: NMR

Omslagsfoto: Ida 5 år

Tryck: Rosendahls-Schultz Grafisk

Upplaga: 130

Printed in Denmark

Denna rapport är utgiven med finansiellt stöd från Nordiska ministerrådet. Innehållet i rapporten avspeglar inte nödvändigtvis Nordiska ministerrådets synpunkter, åsikter eller rekommendationer.

\section{www.norden.org/sv/publikationer}

\section{Det nordiska samarbetet}

Det nordiska samarbetet är ett av världens mest omfattande regionala samarbeten. Det omfattar Danmark, Finland, Island, Norge och Sverige samt Färöarna, Grönland och Åland.

Det nordiska samarbetet är politiskt, ekonomiskt och kulturellt förankrat och är en viktig partner i europeiskt och internationellt samarbete. Den nordiska gemenskapen arbetar för ett starkt Norden i ett starkt Europa.

Det nordiska samarbetet ska stärka nordiska och regionala intressen och värderingar i en global omvärld. Gemensamma värderingar länderna emellan bidrar till att stärka Nordens ställning som en av världens mest innovativa och konkurrenskraftiga regioner.

\section{Nordiska ministerrådet}

Ved Stranden 18

DK-1061 København K

Telefon (+45) 33960200

www.norden.org 


\section{Innehåll}

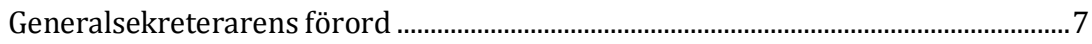

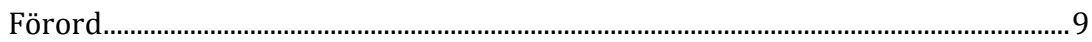

Sammanfattning ................................................................................................

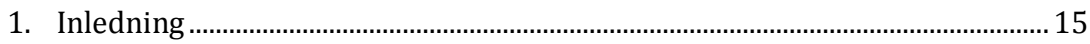

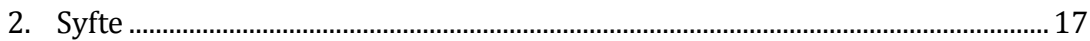

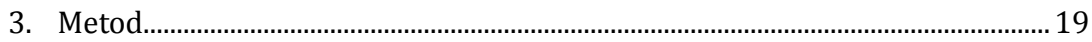

3.1 Tillvägagångssätt ..................................................................................... 19

3.2 Sökstrategi.................................................................................................. 19

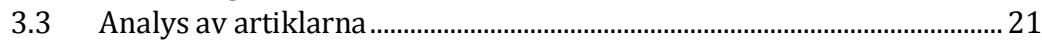

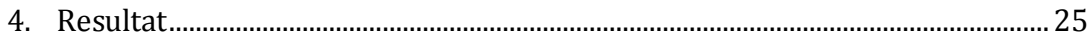

4.1 Vilka aspekter av barnens hälsa påverkas av medier och hur förklaras denna påverkan? .........................................................................2 25

4.2 Vilken roll spelar föräldrarna och den övriga familjen i den påverkan som medier kan ha på barnens hälsa och på vilket sätt

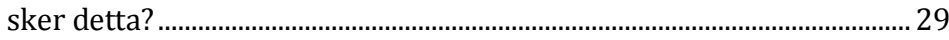

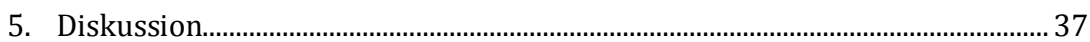

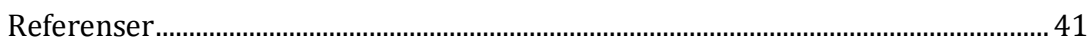

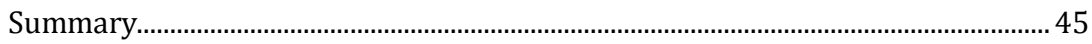





\section{Generalsekreterarens förord}

Alltför många barn och ungdomar i Norden rör på sig för lite och äter dåligt. På kort sikt leder den bristande fysiska aktiviteten och de ohälsosamma kostvanorna bland annat till övervikt. På längre sikt ger det en ökad risk för sociala problem och långvariga hälsorelaterade konsekvenser som en ökad risk för diabetes typ 2, fetma, cancer och förhöjt blodtryck. Inte nog med att det är en tråkig framtid som dessa barn och ungdomar går till mötes, men det är också dyrt för de nordiska samhällena.

Antalet människor med livsstilsrelaterade sjukdomar och kroniska sjukdomar ökar och tar den absoluta merparten av hälso- och sjukvårdens resurser i anspråk. Den dominerande praxis som rått hittills har varit att behandla hälsoproblem i takt med att de uppstår. Men nytänkande, där man går från ett behandlingssamhälle med dyra kortsiktiga lösningar till ett förebyggandesamhälle med hållbara lösningar, skulle kunna minska de ekonomiska kostnaderna och slöseriet med mänskliga resurser.

Det uppstår emellertid en fråga om hur de nordiska länderna på ett effektivt sätt kan stärka de förebyggande åtgärderna på social- och hälsoområdet, däribland bidra till att bromsa ökningen av kroniska sjukdomar. Nordiska ministerrådet har gett Nordic School of Public Health NHV (tidigare Nordiska högskolan för folkhälsovetenskap) i uppdrag att svara på denna fråga.

Projektet "Hälsofrämjande och förebyggande" ingår i Nordiska ministerrådets globaliseringsinitiativ om hälsa och välfärd. Initiativet sätter fokus på hur den nordiska välfärdsmodellen kan vidareutvecklas så att den kan klara sig i den globala konkurrensekonomin och bevara sammanhållningen.

Nordiska Livsstilsverkstan - En modell för intersektoriell samverkan mellan föräldrar, förskola, hälsoväsende och forskare är ett konkret resultat av projektets arbete. Forskning tyder på att livsstilsjukdomar fortfarande påverkar yngre människor och det är viktigt att medvetandegöra föräldrar om riskfaktorer och i synnerhet vad som främjar deras barns hälsa. Sådana åtgärder bör redan sättas in när barnen är i förskoleåldern, fram- 
häver forskarna bakom projektet. På det sättet blir en hälsosam livsstil en integrerad del av de ungas och familjernas vardag.

Traditionellt sett är familjen ett viktigt samarbetsområde mellan de nordiska länderna. Familjen är en grundläggande gemenskap i samhället som starkt präglar och formar de framtida nordiska medborgarna. Ett välfungerande familjeliv är en av de viktigaste förutsättningarna för medborgarnas välbefinnande och livskvalitet. Det nordiska samarbetet berör familjefrågor ur många olika vinklar: De nordiska länderna samarbetar för att främja barn och ungdomars välbefinnande, vidareutveckla den nordiska välfärdsmodellen för att garantera trygga levnadsvillkor för nordborna, utveckla den nordiska jämställdhetspolitiken så att den gagnar familjelivet och i ännu högre grad satsa på att öka de äldres deltagande i samhällslivet.

Nordiska Livsstilsverkstan är ett viktigt bidrag till detta arbete.

Köpenhamn den 10 januari 2013

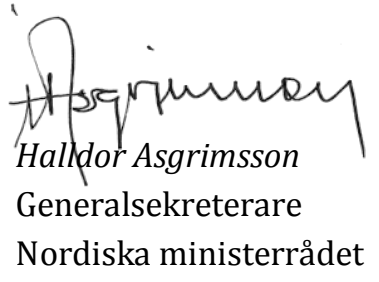




\section{Förord}

Denna rapport är skriven inom ramen för Nordiska ministerrådets satsning, Globaliseringsinitiativet (www.norden.org), och vid arbetet med delprojekt 4 inom området Hälsa och välfärd/Sundhedsfremme og förebyggelse - Nordiska Livsstilsverkstan - En modell för intersektoriell samverkan mellan föräldrar, förskola, hälsoväsende och forskare. Slutrapport och Handledarguide finns publicerade i TemaNords rapportserie i pappersversion men kan också laddas ned från Internet www.norden.org (TemaNord 2013:503, TemaNord 2013:504).

De första idéerna och konceptet till Nordiska Livsstilsverkstan arbetades fram 2009 tillsammans med en referensgrupp sammansatt av personer från alla nordiska länder anställda vid social- och utbildningsdepartementen. Nordiska Livsstilsverkstan har utvecklats under perioden 20102012. För att ge ett fylligt, vetenskapligt faktainnehåll till de olika temaavsnitten i Nordiska Livsstilsverkstan har samarbete skett med forskare från samtliga nordiska länder inom forskningsprojektet Nordiska barns och ungas hälsa och välfärd (NordChild) (www.nhv.se) samt med forskare vid Göteborgs- och Lunds universitet, Sverige.

Nordiska Livsstilsverkstans huvudsyfte är att deltagarna, föräldrar och professionella som arbetar med barn, skall skaffa sig kunskap om och förståelse av samband mellan livsstil och hälsa, hur det påverkar den egna, barnets och familjens hälsa samt att de reflekterar över hur man kan omsätta denna kunskap och insikt i praktiken. En förhoppning är att kunskapen skall föras över till barnen så att de i framtiden på egen hand kan göra hälsosamma livsstilsval. Arbetet bygger på samverkan mellan sektorer; familjen, förskolan, hälsoväsendet, barnavårdscentraler, familjecentraler och forskare. En viktig aktör i detta sammanhang är medier och hur man skall tolka de budskap som medier för fram. Det är mot bakgrund av detta som denna rapport kommit till. 
Fil. dr Gabriella Sandstig, Institutionen för journalistik, medier och kommunikation, Göteborgs universitet, Sverige, har gjort litteratursökningarna och skrivit samman manuskript.

Professor Bengt Johansson, Institutionen för journalistik, medier och kommunikation, Göteborgs universitet, Sverige, har granskat manuskriptet.

Professor Karin C Ringsberg, Nordic School of Public Health NHV, Göteborg, har granskat och redigerat manuskriptet samt tagit fram material till faktarutorna.

Docent Leeni Berntsson, Nordic School of Public Health NHV, Göteborg, har genomfört de statistiska beräkningarna till faktarutorna.

Tack alla som bidragit till denna rapport!

Göteborg den 18 december 2012

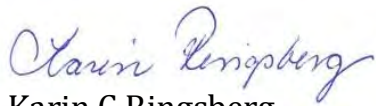

Karin C Ringsberg

Professor, projektledare, redaktör

Nordic School of Public Health NHV 


\section{Sammanfattning}

I diskussionen kring barns hälsa och faktorer, som främjar hälsa, lyfts ofta fram att alltför mycket TV-tittande, användande av datorspel och Internet m.m. är skadligt för barns hälsa.

Syftet med denna rapport var att göra en litteraturöversikt genom att göra en systematisk genomgång av empiriska studier eller litteraturstudier presenterade i vetenskapligt granskade artiklar som undersökt mediers påverkan på förskolebarns hälsa (3-5 år) med avseende på

- vilka aspekter av barnens hälsa som påverkas av medier och hur denna påverkan förklaras

- vilken roll föräldrarna och den övriga familjen spelar i den påverkan som media kan ha på barnens hälsa och på vilket sätt.

En sökning av vetenskapligt granskade artiklar gjordes i databaserna: Social Science Citation Index (SSCI) för att finna medie- och kommunikationsartiklar, the U.S: National Library of Public Health (PubMed) för att finna hälsoaspekter och Nordicom Media Research Publications (Ncom) för att få det specifikt nordiska perspektivet samt Academic Search Elite (EBSCO), då denna databas kunde innehålla artiklar som inte återfinns i andra databaser.

De termer och motsvarande betydelser som sökts var: (media and influence and child) och (parent or health). Artiklar söktes för åldersgruppen 3-5 år.

Antalet artiklar, som uppfyllde inklusionskriterierna, var 49.

Analysen av artiklarna visade, att mediernas påverkan på barns hälsa och förklaringsmodeller kunde sammanställas i fyra teman:

- beteende, moraliska resonemang, mental hälsa

- vikt, kost och fysisk aktivitet

- reklam

- sociala och kognitiva färdigheter. 
De aspekter av förskolebarns hälsa, som medierna framför allt påverkar, är aggressioner, övervikt och fetma, bristen på utveckling av sociala och kognitiva färdigheter samt konsumtionsmönster. Detta gäller såväl äldre typer av medier, som TV och nyare, som Internet och dataspel. Som förklaring hänvisar de granskade artiklarna till olika sociala teorier som social inlärningsteori och imitation av beteenden. Det framkom i artiklarna, att det föreligger samband mellan mängden tid, som barn i förskoleåldern exponeras för medieinnehåll, och negativa utfall på hälsan. Det diskuterades också hur stillasittande aktiviteter, som TV-tittande, tar tid från andra aktiviteter, som kan vara gynnsamma för att utveckla en hälsosam livsstil.

Rörande vilken roll föräldrarna och den övriga familjen spelar i den påverkan, som media kan ha på barnens hälsa och på vilket sätt, kunde artiklarna sammanställas i tre tema:

- familjeresurser

- föräldramedling

- föräldrars attityder och engagemang.

Artiklarna visade att det finns stark korrelation mellan högkonsumerande medieanvändande föräldrar och högkonsumerande medieanvändande barn. Vidare har låg hushållsinkomst och låg utbildning samband med ökat TV - tittande bland alla familjemedlemmar.

Artiklarna visade också, att föräldrar kan hindra sina barn från skadligt medieinnehåll genom sina egna negativa attityder gentemot medierna, medieinnehåll och mediepåverkan. De kan också påverka genom att kombinera denna attityd med engagemang i barnet genom gemensamt tittande eller lärorik medling, där den förra enligt de granskade artiklarna är vanligare bland barn i förskoleåldern än de två sistnämnda. Den primära typen av medling som används för barn i åldern 3-5 år är den restriktiva. I denna litteraturöversikt framkom att föräldrarnas attityder till medierna och denna attityds påverkan är viktigare än deras eget mediebeteende eller typer av föräldramedling och att föräldrarnas kulturella resurser som högre utbildning betyder mer än deras materiella.

Resultaten från litteraturöversikten visar också att både föräldrarnas oro över de negativa effekterna på deras egna barn samt deras uppfattningar om de negativa effekterna på andras barn i allmänhet korrelerar 
med föräldramedlingen men att riktningen och storleken på detta samband varierar.

Sammanfattningsvis skulle det vara intressant att i framtiden fortsätta att studera betydelsen av familjens socioekonomiska och kulturella resurser och föräldrars attityder samt vilka konsekvenser föräldrars aktiva beteende har och då i relation till riktigt små barn. 



\section{Inledning}

Den generella välfärden har ökat, sett ur ett globalt perspektiv, men det finns fortfarande stora skillnader mellan hög- och låginkomstländer (www.who.org). Många låg- och medelinkomstländer har, till skillnad mot de flesta västerländska samhällen, stora problem med smittsamma sjukdomar, fattigdom, brist på mat, vatten och underutvecklade sjukvårdsoch skolsystem. I de västerländska samhällena breder de så kallade livsstilssjukdomarna ut sig, men man har också sett att dessa i stor utsträckning finns i låg- och medelinkomstländer. Man brukar tala om att dessa länder har en "dubbel sjukdomsbörda" (Beaglehole \& Bonita, 2008).

Den ökade välfärden kan leda till olika typer av välfärdssjukdomar, som t.ex. stress, fetma, diabetes, psykisk ohälsa och dessa bidrar till allvarliga hälsoproblem i många länder (www.who.org). Ur detta perspektiv måste barns hälsa, och faktorer som kan orsaka hälsoproblem hos små barn, ses som en central fråga. Förhoppningsvis kan en hälsosam livsstil i unga år minska risken för att utveckla ohälsa senare i livet.

Mediers roll tas ofta upp i detta sammanhang. Speciellt när ett nytt medium introduceras förefaller det finnas det spekulationer om att mediet inte alltid gynnar en hälsosam livsstil.

Inom medieforskningen har man sedan 1940-talet studerat mediernas inverkan på barn och ungdom. Effekten av exponering för medier i allmänhet (antal timmar barnet tittar på TV etc.) eller hur exponering för ett visst innehåll påverkar hälsan, har studerats. Fokus har framför allt varit på äldre barn och ungdom. Däremot förefaller intresset för att studera medieinverkan på barn i förskoleåldern och olika aspekter av deras hälsa ha varit lågt.

Familjen utgör ett socialt sammanhang för barn. Föräldrarnas roll och deras påverkan är stor, inte minst när det gäller de små barnen. De samtida stora förändringarna i medielandskapet tyder också på att familjens kommunikations-mönster håller på att förändras (Bjur, 2009). Mot bak- 
grund av detta är det även av intresse att se på föräldrarnas och övriga familjens roll i det inflytande som medierna kan ha på förskolebarns hälsa.

Nordic School of Public Health NHV, genomförde under åren 20102012 ett projekt finansierat av Nordiska ministerrådet, NMR, vars syfte var att skapa ett föräldrastödsprogram (Nordiska Livsstilsverkstan) för att främja en hälsosam livsstil bland föräldrar och förskolbarn (3-5 år) i Norden, (www.norden.org; www.nhv.se). Det är därför av intresse, att se vad som är beskrivet i vetenskapliga studier rörande medieexponering och dess hälsoeffekter på förskolebarn. Det är också av intresse att se, vilka centrala teorier som används för att förklara mekanismerna bakom påverkan från medierna på förskolebarns hälsa. 


\section{Syfte}

Syftet med denna litteraturöversikt var att göra en systematisk genomgång av empiriska studier eller litteraturstudier presenterade i vetenskapligt granskade artiklar, som undersökt mediers påverkan på förskolebarns hälsa (35 år) med avseende på: TV, dvd, videospel, dataspel, Internet och reklam.

- Vilka aspekter av barnens hälsa påverkas av medier och hur förklaras denna påverkan?

- Vilken roll spelar föräldrarna och den övriga familjen i den påverkan som medier kan ha på barnens hälsa, och på vilket sätt sker detta? 



\section{Metod}

\subsection{Tillvägagångssätt}

Potentiella artiklar för analys identifierades genom systematiska sökningar i fyra databaser. Sedan dubbletter sorterats bort återstod 415 artiklar. Samtliga abstracts till dessa artiklar lästes igenom för att sortera fram artiklarna som uppfyllde inklusionskriterierna för denna litteraturstudie. Efter denna första sortering återstod 49 artiklar att läsa igenom i sin helhet och analysera. Dessa utgör det empiriska materialet för denna studie.

\subsection{Sökstrategi}

Sökning gjordes i Social Science Citation Index (SSCI), för att finna medieoch kommunikationsartiklar, the U.S: National Library of Public Health (PubMed), för att finna hälsoaspekter och Nordicom Media Research Publications (Ncom), för att få det specifikt nordiska perspektivet, samt Academic Search Elite (EBSCO), då denna databas kunde innehålla artiklar som inte återfinns i de andra valda databaserna. Inga årsgränser angavs. Det tillgängliga utbudet av år i de olika databaserna var olika.

Två sökningar gjordes; den första genomfördes under hösten 2010, den sista under påföljande vår 2011: SSCI: 1956-; Ncom: - 1975; EBSCO: 1985-; i PubMed var intervallet beroende av tillgången till databasens tidskrifter, och kan därför inte anges.

Sökningen byggdes upp kring tre sökningar:

- Artiklar som rörde det allmänna inflytande, som föräldrar kan ha rörande den påverkan som medierna kan ha på barn i förskoleåldern (3-5 år).

- De olika sätt som medierna direkt kan påverka barn i förskoleålderns (3-5 år) hälsa. 
- Den roll som föräldrarna kan spela i den påverkan medierna kan ha på barn i förskoleålderns (3-5 år) hälsa.

\section{Inklusionskriterier}

Artiklarna skulle:

- avse empirisk forskning från kontrollerade studier eller vara resultatet av en litteraturöversikt (forskningskriteriet)

- undersöka medier (mediekriteriet)

- undersöka mediers påverkan (påverkanskriteriet)

- gälla barn i förskoleåldern 3-5 år (ålderskriteriet)

- antingen undersöka föräldrar (föräldrakriteriet) eller hälsorelaterade frågor (hälsokriteriet)

- vara vetenskapligt granskade studier som publicerats i en redigerad tidskrift (peer review-kriteriet)

- vara skrivna på engelska eller skandinaviska (språkkriteriet).

Sökningen var initialt bred och inleddes med att identifiera potentiella artiklar med hjälp av sökorden: medier, inflytande, barn, föräldrar och hälsa, och motsvarande betydelser. Motsvarande betydelser för medier var (Media* or television* or tv* or video* or dvd* or computer* or web* or internet*), för inflytande (effect* or influence* or perception* or "spiral of silence" or "agenda setting" or "two-step flow of communication" or cultivation or "uses and gratification" or "parental mediation" or "social learning" or "third-person effect" or TPE or "third-person perception" or TPP or "third-person effects hypothesis" or "behavioral consequences" or "reversed third-person effects" or "first-person perception"), för barn (child* or preschool*), för föräldrar (parent* or caretaker*) och för hälsa (Health*). Enligt de sökfält som fanns tillgängliga: medier och inflytande söktes i SSCI, EBCSO och PubMed i titeln; föräldrar och hälsa och barn söktes i SSCI i ämnet, i EBCSO i abstrakt och i PubMed i titeln/abstrakt. I Ncom fanns inga sådana detaljerade val tillgängliga.

Ämnena och deras motsvarande betydelser kombinerades i tre sökningar:

- medier och påverkan och barn och föräldrar

- medier och påverkan och barn och hälsa

- medier och påverkan och barn och föräldrar och hälsa. 
Resultaten från sökningen framgår av tabell 1.

Tabell 1: Antal potentiella artiklar som uppfyllt kriterierna för att inkluderas i studien

\begin{tabular}{|c|c|c|c|c|c|c|c|c|c|c|}
\hline \multirow[t]{2}{*}{ Data-baser } & \multicolumn{3}{|c|}{$\begin{array}{c}\text { Medier och } \\
\text { påverkan och } \\
\text { barn och förälder }\end{array}$} & \multicolumn{3}{|c|}{$\begin{array}{l}\text { Medier och } \\
\text { påverkan och } \\
\text { barn och hälsa }\end{array}$} & \multicolumn{3}{|c|}{$\begin{array}{c}\text { Medier och } \\
\text { påverkan och } \\
\text { barn och förälder } \\
\text { och hälsa }\end{array}$} & \multirow[t]{2}{*}{$\begin{array}{r}\text { Potentiella } \\
\text { artiklar utan } \\
\text { dubbletter }\end{array}$} \\
\hline & $\underset{:}{\stackrel{\mathscr{\varepsilon}}{\xi}}$ & 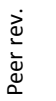 & $\begin{array}{l}\frac{.}{\text { त. }} \\
\text { जँ }\end{array}$ & 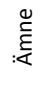 & 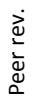 & 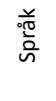 & $\underset{:}{\stackrel{\mathscr{\varepsilon}}{<}}$ & 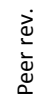 & 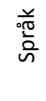 & \\
\hline $\mathrm{SSCl}$ & 237 & 207 & 204 & 166 & 146 & 141 & 63 & 58 & 57 & 284 \\
\hline PubMed & 152 & 152 & 149 & 116 & 116 & 110 & 38 & 38 & 37 & 223 \\
\hline EBSCO $^{1}$ & 117 & 117 & 114 & 47 & 47 & 47 & 23 & 23 & 23 & 139 \\
\hline Ncom & 18 & 4 & 3 & 6 & 1 & 1 & 0 & 0 & 0 & 4 \\
\hline $\begin{array}{l}\text { Utan } \\
\text { dubbletter }\end{array}$ & & & & & & & & & & 415 \\
\hline
\end{tabular}

Kommentar: ${ }^{1}$ I EBSCO antas artiklarna vara på engelska (inget språkval tillgängligt).

Sedan dubbletter sorterats bort återstod 415 artiklar. Vid genomläsning av abstracts kunde 366 artiklar sorteras bort, då de inte uppfyllde de uppsatta inklusionskriterierna (se ovan); 212 handlade inte om massmedier, 45 inte om mediers inflytande och 107 handlade inte om barn i åldern 3-5 år, en artikel var inte vetenskapligt granskad och en var skriven på spanska. Antal artiklar som återstod för genomläsning och analys var 49 stycken.

\subsection{Analys av artiklarna}

Artiklarna analyserades utifrån följande fyra frågeställningar:

- Vad är fokus eller de viktigaste målen för studien?

- Vilka är de centrala frågeställningarna?

- Vilka är de viktigaste resultaten? Vilka mediefaktorer är det som utövar påverkan? Vilket inflytande har medierna i jämförelse med andra faktorer? Vilka aspekter av barns i förskoleålderns hälsa påverkas?

- Vilka teorier används för att förklara mediernas påverkan på barn i förskoleåldern? 
Tabell 2. Artiklar som ingår i litteraturöversikten sorterade efter vilka typer av medier som påverkar vilka aspekter av förskolebarnens hälsa och vilken sorts

påverkan av föräldern

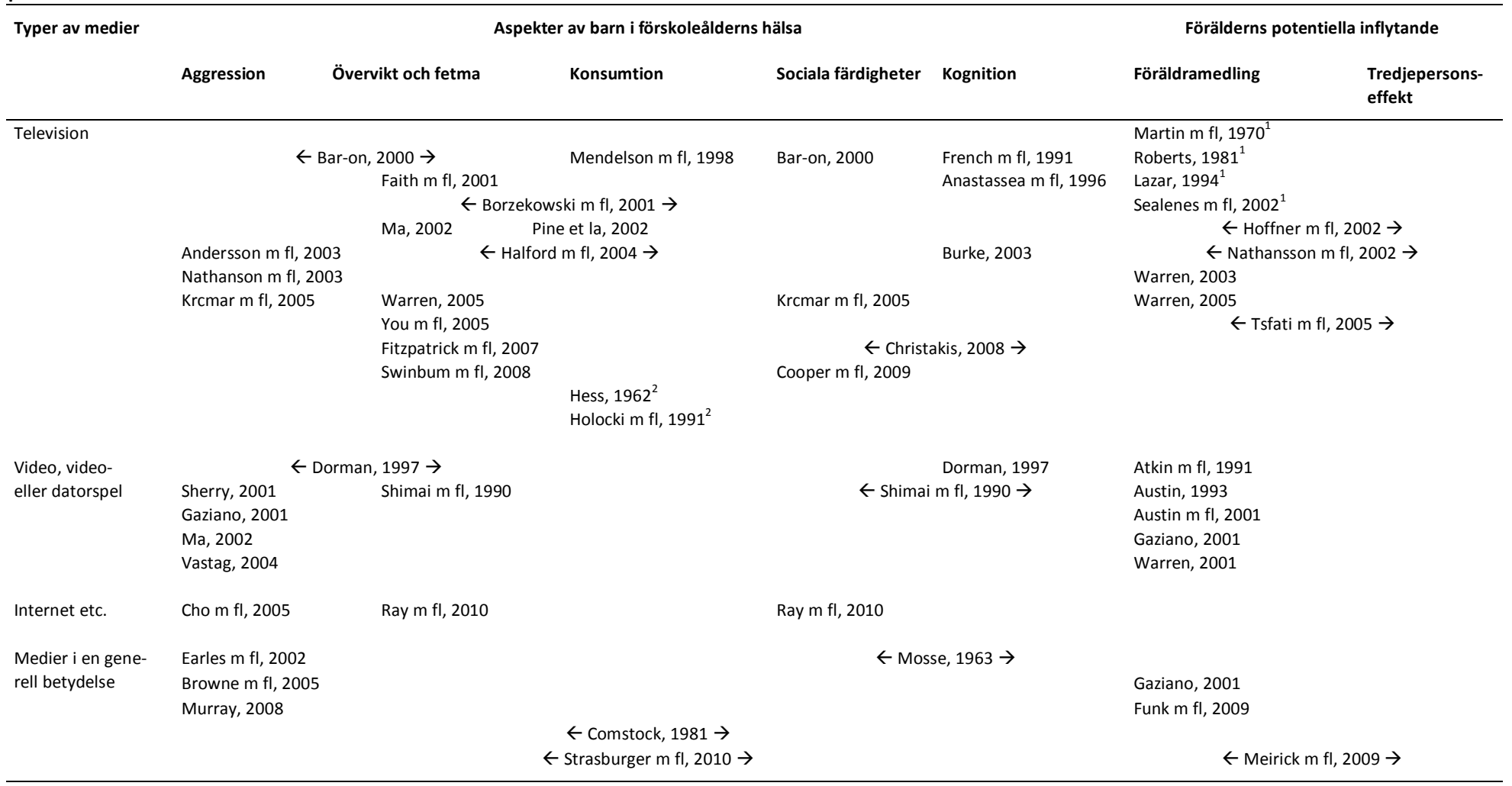

Kommentarer:

${ }^{1}$ Handlar inte specifikt om föräldramedling men avser frågor som berör relationen mellan förälder och barn eller familjesammanhanget.

${ }^{2}$ Handlar inte specifikt om aspekter av hälsa. 


\section{Uppgifter till fakta rutorna}

De statistiska uppgifterna är hämtade från Nordiska studien "Hälsa och välfärd bland barn och ungdom i de nordiska länderna (NordChild). I en longitudinell studie har data insamlats i samtliga nordiska länder rörande barn i åldern 2-17 år för åren 1984, 1996 och 2011. De flesta frågor är desamma, men några framför allt de om media har lagts till 2011 års studie www.nhv.se. Data för de yngsta barnen redovisas i det materialet för åldersgruppen 2-6 år. 



\section{Resultat}

\subsection{Vilka aspekter av barnens hälsa påverkas av medier och hur förklaras denna påverkan?}

Analysen av artiklarna visade att mediernas påverkan på barns hälsa och förklaringsmodeller för detta kunde sammanställas i fyra tema:

- beteenden, moraliska resonemang, mental hälsa

- vikt, kost och fysisk aktivitet

- reklam

- sociala och kognitiva färdigheter.

\subsubsection{Beteenden, moraliska resonemang, mental hälsa}

Studiet av medieeffekter på barns hälsa har historiskt sett nästan varit synonymt med studier av effekterna av TV-våld på barns beteenden (Gaziano, 2001). Flera studier (Lowery \& DeFleur, 1995; Murray, 2008) visar att TV-våld, både på kort och på lång sikt, påverkar barns attityder, värderingar och beteenden till att bli mer aggressiva. En studie av effekterna av TV-tittande med våldsinslag på förskolebarns moraliska resonemang visade t.ex. en negativ effekt på deras resonemang om motiverat våld (Krcmar, 2005). Ingen särskild teori fördes fram som förklaring, men det antyddes av författaren, att en förklaring kunde vara att barnet lärde sig genom titta på, imitera och assimilera beteenden, som visas på skärmen (ibid.). I en annan studie förklarades liknande resultat med hjälp av social inlärningsteori (Earles et al., 2002). Strasburger, Jordan och Donnerstein (2010) menar att påverkan gäller särskilt om medieinnehållet exponerar realistiska och belönande beteenden, så att barnet kan identifiera sig med rollfiguren (super-peer-teorin). Medierna blir som mäktiga bästa vänner, vilka gör att ett riskfyllt beteende förefaller vara ett normalt beteende. Barn i förskoleåldern, som spelar våldsamma videospel, kan bli upprymda 
på ett liknande sätt, som när de tittar på TV-serier (Dorman, 1997). Sherry (2001) har vid en metaanalys rörande effekten av TV-spel (t.ex. Mortal, Combat och Doom) och utveckling av aggressioner funnit att effekten av våldsamma videospel är mindre än effekterna av TV-våld. Orsaken till att spelandet av videospel kan utlösa aggressivt beteende har förklarats med hjälp av upphetsningsteori (arousal theory) och katharsisteorin. Den förra upphetsningsteorin säger att det mest sannolika, när barn blir upphetsade, är att de kommer att bete sig på det sätt, som de senast observerat. Den senare, katharsisteorin, säger att genom att agera ut känslomässiga drifter, kan de aggressiva nivåerna minskas (Dorman, 1997). Upprepad exponering för medierat våld kan leda till ångest och rädsla hos barn men också till acceptans av våld, som lämpligt medel för att lösa konflikter (Anderson et al., 2002). Strasburger et al. (2010) menar att det kan leda till en minskad sensibilitet och minskning av altruism.

\subsubsection{Vikt, kost och fysisk aktivitet}

Hur mycket och hur länge barnet tittar på TV har en stark positiv korrelation med fetma och fysisk inaktivitet (Faith et al., 2001). Varje timmes ökning av TV-tittande var i en annan studie associerad med 1-2 procents ökning i förekomsten av fetma (Ma et al., 2002). Denna negativa påverkan förklaras av Dorman (1997) med att TV-tittandet som en verksamhet tar tid från andra aktiviteter som är gynnsamma för hälsan, särskilt fysiska aktiviteter. 


\section{Faktaruta}

Av nordiska barn i åldern 2-6 år

- $\quad \operatorname{var} 0,4 \%(n=12)$ överviktiga(N=2 562) 1996 och 0,4\% (n=8) $2011(\mathrm{~N}=2$ 078)

- $\quad$ ansträngde sig 63,3 \% (n=1 787) fysiskt minst en gång varje vecka så att de blev svettiga $1996(\mathrm{~N}=2$ 821) och 79,7 \% ( $\mathrm{n}=1$ 321) $2011(\mathrm{~N}=1748)$

- $\quad$ tittade 74,2 \% ( $\mathrm{n}=1$ 658) dagligen på TV/DVD/video $2011(\mathrm{~N}=2$ 236)

- $\quad$ spelade 8,8 \% ( $\mathrm{n}=196)$ dagligen dataspel $2011(\mathrm{~N}=2$ 209)

- surfade 1,1 \% (n=25) dagligen på Internet $2011(\mathrm{~N}=2$ 209).

Källa: NordChild 2011.

Halford et al. (2004) menar, att på grund av det ökade tittandet, antas barnen inte få tillräckligt med sömn och därigenom ökar sannolikheten för ett stillasittande beteende. Men samme författare menar också att fetma och TV-tittande inte bara ses i ljuset av stillasittande aktivitet (ibid.). En annan studie visar på, att det finns ett samband mellan att äta måltider framför TV:n och en ökning av barnens vikt också från tidigt i barndomen (You \& Nayga, 2005). Strasburger et al. (2010) förklarar barnens ökade vikt med att mättnadskänslan undertrycks när barnen tittar på TV medan Fitzpatrick et al. (2007) menar att de positiva effekterna av familjemiddagar (och att servera frukt m.m.) överträffas av TV-tittande.

\subsubsection{Reklam}

Barns exponering för reklam för mat på TV har visat sig öka intaget av mängden mat (Halford et al., 2004; Arnas, 2006). Barnen ber sina föräldrar att köpa de produkter de sett på TV-reklamen, både medan de tittar på TV och när de handlar (Arnas, 2006). Detta gäller särskilt "snacks" bland barn med fetma och övervikt, men också bland de magra (ibid.). Det finns också en förhöjd beredskap till matrelaterade budskap bland barnen med fetma som inte återfinns hos de magra eller överviktiga barnen (Halford et al., 2004). TV-reklam påverkar särskilt små barns konsumtion av ohälsosam mat (Arnas, 2006). Borzekowski et al. (2001) har visat att även kort exponering för matreklam på TV kan påverka förskolebarns matpreferenser. Warren (2005) menar dock att även om snabbmat och TV- 
tittande kan påverka fetma och kost, krävs det en drastisk minskning av snabbmatsintaget för att kvaliteten på maten ska ha betydelse för att öka fetman (Warren, 2005).

En studie av TV-reklamens effekter på unga barn i England visade att när barnen tittade på TV ensamma var de mer mottagliga för reklam än en grupp barn, som inte var utsatta för reklam (Pine \& Nash, 2002). Det visade sig att jämförelsegruppen med barn från Sverige, där reklam riktad till barn inte är tillåtet, bad om betydligt färre antal leksaker och färre märkesvaror. I samma artikel diskuteras att engelska barn som tittar mer på TV, och speciellt de som tittar ensamma, kan socialiseras till att bli konsumenter från en mycket tidig ålder. Det finns också studier, som hänvisar till kognitiv utvecklingsteori, som visar att barn under åtta år är särskilt sårbara för reklam, eftersom de inte alltid kan förstå det övertygande syftet med reklam (Strasburger et al., 2010).

\subsubsection{Sociala och kognitiva färdigheter}

Ray och Jat (2010) har visat att TV-tittande och användning av övriga elektroniska medier tar tid från andra aktiviteter, som främjar sociala färdigheter som att utveckla vänskapsrelationer. Ju mer tid barnen tillbringar med att titta på TV, desto mindre tid tillbringar de med sina vänner och familj. Trots att TV-tittandet också är en social aktivitet, menar författarna att konsekvenserna av alltför mycket TV-tittande, på bekostnad av att utveckla sociala relationer, ökar risken för social isolering, ångest, agorafobi, och antisocialt beteende, aggression och gängbildning. De påpekar emellertid att det omvända orsakssambandet också är troligt, d.v.s. att ensamma barn vänder sig till TV för underhållning och kamratskap. Oavsett hur orsakssambanden ser ut, visar forskning att barn som är socialt integrerade tillbringar mindre tid med att titta på TV (ibid.).

Hur mycket barnen tittar på TV har också visat sig ha samband med nedsatt koncentrationsförmåga och bristande uppmärksamhet, både vad avser hyper- eller hypoaktivitet (Christakis, 2009). Samme författare har funnit, att effekterna av mediernas innehåll (som Batman, eller Power Rangers) på uppmärksamheten är kortsiktiga, mätt direkt efter exponering. Det finns dock longitudinella studier som visar att spädbarns TVtittande kan leda till nedsatt koncentrationsförmåga och impulsivitet, när 
barnet fyller tre och fyra år (ibid.). I studier, som experimentellt har redigerats, har man påvisat att snabba klipp i TV-innehåll har effekt på barns grad av uppmärksamhet (Cooper et al., 2009). Enligt Ray och Jat (2010) tittar barn med ADHD mer på TV än sina jämnåriga och har större svårigheter att förstå berättelser. Men det finns också studier, som inte visar på några effekter av TV-tittandet (ibid.).

Anatessea (1996) har i en studie av grekiska barns TV-vanor funnit att det finns samband mellan utbildningsresultat och vid vilken ålder barn börjar titta på TV. I studien påvisades att de elever, som presterade väl, också var de barn, som tidigare i livet hade börjat titta på TV än de elever som presterade sämre. Den senare gruppen såg däremot mer på TV, i likhet med barn från tätorter och från lägre socioekonomiska grupper (ibid.). När det gäller påverkan på framför allt de yngre barnen, har medierna visat sig ha mer positiva effekter. Vissa TV-program riktade mot mycket unga barn (3-5 år) (såsom "Sesame Street") har studier från början av 1970-talet visat att de främjar både sociala beteenden och har positiva pedagogiska effekter på barnet (Bar-on, 2000; Christakis, 2008). I en studie av French (1991) undersöktes förändringarna i superhjälteteman i barns lek under de senaste femtio åren och påverkan av superhjältar från TV diskuterades. Resultatet tydde på att det hade skett en ökad dramatisering av superhjälteteman i barns lek i allmänhet men att denna påverkan också främjade barnens fantasilekar (French, 1991).

\subsection{Vilken roll spelar föräldrarna och den övriga familjen i den påverkan som medier kan ha på barnens hälsa och på vilket sätt sker detta?}

Analysen av artiklarna visade att föräldrarnas och den övriga familjens roll rörande mediers påverkan av barnens hälsa kunde sammanställas i tre teman:

- familjeresurser

- föräldramedling

- föräldrars attityder och engagemang. 


\subsubsection{Familjeresurser}

Familjeresurser används här i bemärkelsen lägre materiella och kulturella resurser.

Cho och Cheon (2005) fann att det finns stark korrelation mellan högkonsumerande medieanvändande föräldrar och högkonsumerande medieanvändande barn. Den starkaste indikatorn för att förutsäga högkonsumerande barns medieanvändning är enligt Cho och Cheon (2005) föräldrarnas likvärdigt höga användning. Studier, som inkluderar sociodemografiska indikatorer, som låg hushållsinkomst eller utbildning har visat sig ha samband med ett ökat tittande bland alla familjemedlemmar (Warren, 2005). Även fler TV-apparater i hemmet och i barnens rum samt minskad mängd vuxentillsyn och föräldrars känslighet mot negativa effekter ökar TV-tittandet (Warren, 2005). Familjens resurser kan påverka hur vardagen och mediepraktikerna i ett hushåll är strukturerade. Atkin et al. (1991) och Warren (2005) använder en flerdimensionell ansats (Bronfenbrenner's ekologiska teori) för att återspegla medieanvändning snarare än konventionell demografi.

I en studie om exponeringen för TV-spel framkom, att det som gjorde barn mer aggressiva och fientliga inte var spelet i sig, utan bristen på föräldrarnas engagemang i barnets liv (Vastag, 2004). I en annan studie diskuteras att barn från lågresursfamiljer föredrar våldsamt medieinnehåll, vilket förklarades med att föräldrarnas känsla av maktlöshet och auktoritära egenskaper förs vidare till barnen och att barnen därför var speciellt attraherade av skildring av våldsamma maktuttryck i massmedier och våldsamma spel (Gaziano, 2001). Gaziano (2001) hänvisar till Kohns teori om barnuppfostran (1977), då han förklarar att lågresursfamiljer antas vara sämre rustade för att hantera stress, på grund av begränsade resurser, vilket kan leda till svag anknytning till barnen och en brist att svara på barnens känslomässiga behov, som i sin tur kan leda till antisocialt beteende och isolering från andra.

Strasburger et al. (2010) förklarar det ökade TV-tittandet, när mediet var placerat i barnens sovrum, med att föräldrarna då inte kan övervaka barnens användning.

Cho och Cheon (2005) menar att familjen kan påverka förskolebarns pedagogiska färdigheter genom att tillsammans med barnet titta och diskutera TV-program på teman som politik, eller genom att tolka TV-våld 
eller könsroller. I samma studie framkom att familjens kommunikationsmönster kan motverka att hög mediekonsumtion leder till en minskning av sociala färdigheter. Hög familjesammanhållning inverkar positivt på barnens mediekonsumtionsmönster och föräldrakontroll (ibid.). Vidare hävdar de att föräldrar som är mer samspelta tenderar att ha en hög grad av familjekommunikation, är mer medvetna om barnens beteenden och utövar stor kontroll över barnens medieanvändning. De har också upplever också att de har kontroll i högre grad.

\subsubsection{Föräldramedling}

Medling kan förklara hur föräldrar på kort och lång sikt kan förhindra sina barn från skadlig mediepåverkan. På lång sikt kan de genom medling vägleda dem i hur man ska tolka mediers visuella koder och låta dem utvecklas till kritiska mediekonsumenter.

Forskningen rörande föräldramedling har identifierat tre typer av medling: restriktiv medling, gemensamt tittande och lärorik medling. Restriktiv medling omfattar regler som familjen sätter upp kring medieanvändning (hur länge barnet tittar, tillåtet och förbjudet innehåll) och användandet av belöningar eller straff som är kopplade till dessa regler (Warren, 2005, 2003). Gemensamt tittande bygger på att barnet och föräldern har likartade motiv för att titta (gemensamt intresse, för att det är roligt eller av slump), men barnets tittande bestäms av föräldrarnas programval (Warren, 2003). Lärorik medling (instructive mediation) (ibid.) även känd som restriktiv vägledning (restrictive guidance) eller aktiv medling (active mediation) (Nathanson et al., 2003) är när föräldern diskuterar TV:s innehåll i sådana termer som barnet förstår.

Föräldramedling har visat sig vara vanligare i hem med två föräldrar, där föräldra- och barnkontakten antas vara mer frekventa (Atkin et al., 1991). Warren (2005) konstaterar, att det ökade tittandet i lågresursfamiljer skulle kunna öka möjligheterna till föräldramedling, men att det visade sig i hans studie, att lågresursföräldrar i högre utsträckning brukade restriktiv medling och i lägre utsträckning de lärorika, d.v.s. den mer negativa typen av medling. Den främsta indikatorn för att förutsäga lågresursföräldrars restriktiva föräldramedling var deras attityder avseende tittandets negativa påverkan (ibid.). När det gäller de mer positiva sätten att föräldramedla 
menar Warren (2005) att det finns stöd för i forskningen att föräldraresurser i form av kulturellt kapital (utbildning t.ex.) alltid är en mer dominerande faktor än inkomstnivån. Detta då det är mer troligt att högutbildade föräldrar verbalt interagerar med sina barn mer än de med lägre grader av utbildning. Vid en jämförelse av påverkan av föräldrarnas resurser mot deras attityder, visade sig emellertid de senare bättre förutse föräldramedling än resurser (ibid.). Också faktorer utanför hemmet kan förutsäga föräldramedling, där längre arbetstider ledde till mindre föräldra-barn engagemang och därmed till mindre föräldramedling (ibid.).

\section{Faktaruta}

I NordChild studien 2011 framkom följande avseende föräldrar till nordiska barn i åldern 2-6 år:

- $17,3 \%(\mathrm{n}=382)$ begränsade barnens TV/video/DVD tittande i mycket stor utsträckning, ( $\mathrm{N}=2$ 202).

- $23,7 \%(\mathrm{n}=503)$ begränsade barnens TV- och datorspelande, $(\mathrm{N}=2123)$.

- $27,0 \%(\mathrm{n}=567)$ begränsade barnens surfning/bloggning på nätet, $(\mathrm{N}=2$ 097).

- 12,6 \% (n=280) ansåg att det egna barnet påverkades i mycket stor utsträckning av TV/videotittande, ( $\mathrm{N}=2$ 214).

- 8,4 \% (n=181) ansåg att det egna barnet påverkades i mycket stor utsträckning av TV spel/datorspel, ( $\mathrm{N}=2$ 143).

- $8,4 \%(n=178)$ ansåg att det egna barnet påverkades i mycket stor utsträckning av att surfa/blogga på nätet, ( $\mathrm{N}=2$ 116).

- $21,1 \%(n=461)$ ansåg att andras barn påverkas i mycket stor utsträckning av TV/videotittande, ( $\mathrm{N}=2$ 190).

- $19,7 \%(n=428)$ ansåg att andras barn påverkas i mycket stor utsträckning av TV spel/datorspel, ( $\mathrm{N}=2$ 176).

- $22,1 \%(n=480)$ ansåg att andras barn påverkas i mycket stor utsträckning av att surfa/blogga på nätet, ( $\mathrm{N}=2$ 173).

Källa: NordChild 2011. 


\subsubsection{Föräldrarnas attityder och engagemang}

Enligt Warren (2005) har flera studier visat att föräldrar med mycket negativa attityder till TV är mer benägna att engagera sig i alla typer av föräldramedling, särskilt restriktiv.

Detta är också den vanligaste typen av föräldramedling för 3-5 åringar (Warren, 2003). Mängden föräldramedling är å ena sidan relaterad till barnets ålder: ju yngre barnet är, ju mer föräldramedling och å andra sidan till föräldraengagemanget - ju mer engagerad förälder (gör aktiviteter tillsammans med barnet, rekreation, hemmaprojekt och förtroliga samtal), desto vanligare med gemensamt tittande (Warren, 2005).

I en studie av 1-5 åringar konstaterades att om föräldrarna har en positiv inställning till medierna och deras innehåll är de mer benägna att tillåta att barnen tittar längre tid på TV (Funk et al., 2009). Detta leder till ett större engagemang i barnet, och mer användande av lärorik medling. Funk et al. (2009) kopplar samman Beckers teori (1981) om föräldrabarn relationer med föräldramedling och föräldrarnas resurser. Om föräldrars attityder till medier och medieinnehåll är negativa eller skeptiska, kan föräldrarna genom diskussioner med barnet och genom att främja deras kritiska tänkande bidra till framväxten av barn som kritiska mediekonsumenter (Warren, 2003). Austin et al. (2001) relaterar till Banduras sociala inlärningsteori (1986) och förklarar att föräldrarnas tittande på TV-nyheter, gemensamt tittande, positiv föräldramedling och förstärkta diskussioner eller kombinationen med en skeptisk attityd gentemot TVnyheter kan uppmuntra till kritiskt tänkande snarare än tillit till sådana nyhetsmedier, och visar indirekta positiva effekter på politisk socialisering. I en annan studie undersöktes hur föräldrarnas föräldramedlingsstrategier för att hantera våldsamt TV-innehåll växte fram. Barnen (5-12 år) ombads överväga hur verkligt medieinnehållet verkade. De strategier som utvecklades betonade antingen att medieinnehållet faktamässigt inte var riktigt eller att de var socialt orealistiska (Nathanson et al., 2003:111). 
Forskning om föräldramedling visar att regler för att titta på TV och att titta tillsammans med barnet är vanligare bland föräldrar som tror starkt på TV:s påverkan på barn (Warren, 2005; Funk et al., 2009). Attityder rörande mediernas påverkan och konsekvenser av dessa föreställningar för människors agerande är något som studeras inom forskning om tredjepersoneffekter (TPE), även kallat föreställningar om påverkan på tredje person, tredjepersonsperceptioner (TPP). Tredjepersonseffekter handlar inte nödvändigtvis om "riktiga" effekter, utan hänvisar till ett fenomen av social differentiering mellan en själv och andra. Detta innebär att människor tenderar att tillskriva andra människor större påverkan av mediernas budskap än de tillskriver sig själva (Davison, 1983; Perloff, 1999). Det finns få studier som beskriver tredjepersonseffekter (föräldrarnas föreställningar) och barn i förskoleåldern. Fokus för de studier som är gjorda har varit skadligt TV-våld (Hoffner \& Buchanan, 2002; Meirick et al., 2009) såpopera (Tsfati et al., 2005) eller materialism (Meirick et al., 2009). Forskningen kring tredjepersonseffekter kan användas för att bringa klarhet i om föräldrarnas föreställningar om mediernas negativa påverkan speglar deras föreställningar om barn i allmänhet eller deras eget barn specifikt (Hoffner \& Buchanan, 2002). I samtliga tre studier framkommer att föräldrarna tillskriver att andra barn i allmänhet påverkas mer av medier än vad deras egna gör. Rucinski och Salomon (1990) teorin om attribuering (att vi tenderar att tillskriva de som är oss nära beteenden som liknar vårt eget), för att förstå varför dessa föreställningar förekommer, och för att förklara varför föräldrarna brukar tillskriva liknande föreställningar om mediepåverkan på sina barn som på dem själv (Hoffner \& Buchanan, 2002). En tolkning av detta är att barn i denna aspekt ses som en förlängning av sina föräldrar (Nathanson et al., 2002). 
Även om tredjepersoneffekter påvisats i alla tre ovanstående studier och samtliga undersökt sambandet mellan föräldrarnas föreställning om tredjepersonseffekter och föräldramedling, skiljer sig resultaten i termer av karaktär och riktning. I en studie påvisades stora skillnader i föreställningen om påverkan av en känd såpopera på TV på andras barn i allmänhet (barnens vänner) och de egna barnen ledde till färre begränsningar av barnens TV-konsumtion, mindre gemensamt TV-tittande och färre diskussioner om mediernas innehåll med barnen (Tsfati et al., 2005). I studien av Hoffner och Buchanan (2002) av TV-våld, ledde motsvarande föreställning däremot till en ökad föräldramedling (Hoffner \& Buchanan, 2002). Föräldramedlingen förklarades i den studien främst med föräldrarnas allmänna föreställningar om TV:s förmåga att påverka. I studien av Meirick (2009) av materialismen förutsade föräldrarnas tredjepersonsperceptioner inte föräldramedling. Snarare visade föreställningen att medierna påverkade både andras barn i allmänhet och det egna barnet (det som kallas för influence of percieved influence). 



\section{Diskussion}

En bred sökning i olika databaser gjordes till att börja med för denna litteraturstudie. När artiklar därefter sorterades ut efter på förhand uppsatta inklusionskriterier var det förvånansvärt få som uppfyllde dessa kriterier. Det är möjligt att inklusionskriterierna skulle gjorts vidare. Även böcker och rapporter skulle ha kunnat inkluderats, liksom data från Center on media and child health ( $\mathrm{Cmch}$ ) vid Harvard Medical School och Harvard School of Public Health. Då kunde kanske fler artiklar ha hittats på mycket små barn. Nu hittades endast 49, vilket är anmärkningsvärt få. Ingen artikel återfanns, som särskilt speglade det nordiska perspektivet, vilket bör hållas i minnet vid tolkning av resultaten. Några av artiklarna bygger på forskning som nästan är fyrtio år gammal, medan andra artiklar publicerats helt nyligen. Detta innebär att vissa resultat som presenteras är mer universella till sin karaktär, medan andra är mer bundna i tid. Om flera studier kommit fram till samma slutsatser i olika sammanhang bland vilka tiden är en och forskningstradition är en annan, stärker detta de teorier som använts. Antalet artiklar skrivna på vissa tema eller typer av medier varierade. Det fanns t.ex. många studier på temat våld, men endast en på mediers effekter på moral. Fokus på olika typer av medier, eller avsaknaden av fokus på typer av medier, är också relaterat till när mediet introducerades. TV fick vetenskaplig uppmärksamhet på 1950-60-talen, videooch TV-spel på 80-90-talen, datorspel på 1990-talet och Internet och sociala medier på 2000-talet.

Denna litteraturstudie visar att medier som TV, videospel, dataspel, Internet och reklam i dessa, påverkar små barns hälsa negativt. Barnen kan utveckla aggressivt beteende, bli oroliga och påverkas att bli större konsumenter av godis och skräpmat. Det finns samband mellan mycket TV tittande, fetma och övervikt. De sociala och kognitiva förmågorna kan också påverkas negativt men de kan också stimuleras.

Föräldrarna har en viktig roll när det gäller att begränsa tittande med inslag av våld. Genom att förklara olika orsakssammanhang och att peda- 
gogiskt förklara, kan de stimulera barnen till att bli kritiska konsumenter. De artiklar som granskats i denna litteraturstudie visade att föräldrarengagemang är viktigt och att det är en klassfråga.

I de studier som undersökt mediernas påverkan på barn i förskoleåldern är förklaringarna i några fall motsägelsefulla och onyanserade. Det skulle vara intressant att undersöka om stillasittande beteende i form av att läsa böcker har samma negativa hälsoeffekter på fetma som att titta på tv, eller om ADHD kan påverka mängden av TV-tittande eller om den kausala länken snarare är omvänd och i så fall hur. Strasburger et al. (2010) pekar på en longitudinell studie på ungdomar under 26 år som Jordan et al. genomförde 2008 och som visar att medieanvändning bidrar negativt till den nuvarande epidemin av fetma världen över. Men mekanismerna bakom varför de som tittar mycket på TV är signifikant som indikator för att förutsäga barnens ökade vikt är oklar. Här behövs ytterligare studier om vilka andra välfärdsfaktorer som skulle kunna förklara eller motverka fetmaepidemin.

Den samtida diskussionen inom medie- och kommunikationsforskning och yngre barn är relaterad till det kraftigt förändrade medielandskapet med nya användare och användning av medier, där barnen inte längre bara är mottagare av medieinnehåll, utan aktiva deltagare och aktörer i sin mediekonsumtion (Carlsson, 2010; Livingstone \& Haddon 2009; Tufte \& Ekström 2007; von Feilitzen \& Carlsson, 2007). Dessa förändringar tyder på att familjens kommunikations-mönster håller på att förändras, vilket ytterligare sätter fokus på barnet som aktör i sin egen mediekonsumtion, men också en förskjutning mot ett fokus på föräldrarnas och familjens roll i det inflytande som medierna kan ha på barn i förskoleåldern. Media Literacy, d.v.s. hur man kan främja att barn utvecklas till kritiska mediekonsumenter diskuteras allt mer. Forskning rörande media literacy behandlar även bristen på symmetri i de effekter som medierna kan ha inte bara genom att ensidigt undersöka riskerna med mediekonsumtion, utan också möjligheterna som utvecklingen av kreativitet, identitet och deltagande i samhället (Livingstone \& Haddon, 2009).

Det finns, så vitt vi vet, inga studier av vilken typ av föräldrars tredjepersonsperceptioner som leder till vilken typ av föräldramedlingstyp: restriktiv, gemensamt tittande eller lärorik medling. Det skulle vara intressant att i en ny studie använda sig av en typologi som å ena sidan skil- 
jer mellan traditionella tredjepersonsperceptioner (på sig själv, vänner och andra) och föräldrarnas tredjepersonsperceptioner om barn (om egna barn, vänner barn och andra barn) och å den andra sidan mellan olika typer av föräldramedling (restriktiv, gemensamt tittande och lärorik).

\section{Framtida forskning}

Som framgått ovan kan föräldrarnas kulturella och materiella resurser påverka föräldrarnas attityder och beteenden och lägga grunden för hur familjens vardag struktureras, och därigenom sätta ramarna för föräldramedlingens möjligheter och begränsningar. Det vore därför intressant att i en ny studie titta på hur dessa faktorer samverkar.

Inom forskningen kring tredjepersonseffekter har uppfattningar om mediernas påverkan och möjliga konsekvenser som dessa uppfattningar kan ha, studerats. Ovanligt i dessa studier är å ena sidan studier av "riktiga" beteendemässiga konsekvenser (som att föräldrar byter TV-kanaler baserat på deras uppfattning om hur deras barn kan påverkas negativt av mediernas innehåll) och å andra studier av riktigt små barn. Det vore därför intressant att även fördjupa sig inom detta område. 



\section{Referenser}

Anastassea Vlachou, K., Fryssira Kanioura, H., Papathanasiou Klontza, D., Xipolita Zachariadi, A., \& Matsaniotis, N. (1996). The effects of television viewing in Greece, and the role of the paediatrician: A familiar triangle revisited. European Journal of Pediatrics, 155, (12), 1057-1060.

Anderson, C.A., Berkowitz, L., Donnerstein, E., Huesmann, L.R., Johnson, J.D., Linz, D., Malamuth, N.M., \& Wartella, E. (2003). The influence of media violence on youth. Psychological Science in the Public Interest (Wiley-Blackwell), 4, (3), 81-110.

Atkin, D.J., Greenberg, B.S., \& Baldwin, T.F. (1991). The home ecology of childrens television viewing - parental mediation and the new video environment. Journal of Communication, 41, (3), 40-52.

Austin, E.W., \& Pinkleton, B.E. (2001). The role of parental mediation in the political socialization process. Journal of Broadcasting \& Electronic Media, 45, (2), 221-240.

Autstin, E.W. (1993). Exploring the effects of active parental mediation of television content. Journal of Broadcasting \& Electronic Media, 37, (2), 147-158.

Arnas, Y.A. (2006). The effects of television food advertisement on children's food purchasing requests. Pediatrics International, 48, (2), 138-145.

Bar-on, M.E. (2000). The effects of television on child health: implications and recommendations. Archives of Disease in Childhood, 83, (4), 289-292.

Beaglehole, R., \& Bonita, R. (2008). Public health at the crossroads. Achievements and prospects. Cambridge: Cambridge University Press.

Bjur, J. (2009). Transforming audiences. Patterns of individualization in television viewing (avhandling för doktorsexamen, Göteborgs universitet).

Borzekowski, D.L.G., \& Robinson, T.N. (2001). The 30-second effect: An experiment revealing the impact of television commercials on food preferences of preschoolers. Journal of the American Dietetic Association, 101, (1), 42-46.

Carlsson, U. (Eds.). (2010). Children and youth in the digital media culture. Gothenburg: Nordicom, University of Gothenburg.

Cho, C.H., \& Cheon, H. J. (2005). Children's exposure to negative Internet content: Effects of family context. Journal of Broadcasting \& Electronic Media, 49, (4), 488-509.

Christakis, D.A. (2009). The effects of infant media usage: what do we know and what should we learn? Acta Paediatrica, 98, (1), 8-16.

Comstock, G. (1981). Influences of mass-media on child health behavior. Health Education Quarterly, 8, (1), 32-38.

Cooper, N.R., Uller, C., Pettifer, J., \& Stolc, F.C. (2009). Conditioning attentional skills: examining the effects of the pace of television editing on children's attention. Acta Paediatrica, 98, (10), 1651-1655. 
Davison, P. (1983). The third-person effect in communication. The Public Opinion Quarterly, 47, (1), 1-15.

Dorman, S.M. (1997). Video and computer games: Effect on children and implications for health education. Journal of School Health, 67, (4), 133-138.

Earles, K.A., Alexander, R., Johnson, M., Liverpool, J., \& McGhee, M. (2002). Media influences on children and adolescents: Violence and sex. Journal of the National Medical Association, 94, (9), 797-801.

Faith, M.S., Berman, N., Heo, M.S., Pietrobelli, A., Gallagher, D., Epstein, L.H., Eiden, M.T., \& Allison, D.B. (2001). Effects of contingent television on physical activity and television viewing in obese children. Pediatrics, 107, (5), 1043-1048.

Fitzpatrick, E., Edmunds, L.S., \& Dennison, B.A. (2007). Positive effects of family dinner are undone by television viewing. Journal of the American Dietetic Association, 107, (4), 666-671.

French, J., \& Pena, S. (1991). Children's hero play of the 20th century: Changes resulting from television's influence. Child Study Journal, 21, (2), 79-94.

Funk, J.B., Brouwer, J., Curtiss, K., \& McBroom, E. (2009). Parents of preschoolers: Expert media recommendations and ratings knowledge, media-effects beliefs, and monitoring practices. Pediatrics, 123, (3), 981-988.

Gaziano, C. (2001). Toward a broader conceptual framework for research on social stratification, childrearing patterns, and media effects. Mass Communication \& Society, 4, (2), 219-244.

Halford, J.C.G., Gillespie, J., Brown, V., Pontin, E.E., \& Dovey, T.M. (2004). Effect of television advertisements for foods on food consumption in children. Appetite, 42, (2), 221-225.

Hallen, D. (1976). Barn - TV - foreldre. Kirke og kultur, 81, (4), 202-212.

Hess, R.D., \& Goldman, H. 1962. Parents views of the effect of television on their children. Child Development, 33, (3), 411-426.

Hoffner, C., \& Buchanan, M. (2002). Parents' responses to television violence: The third person perception, parental mediation, and support for censorship. Media Psychology, 4, (3), 231-252.

Holicki, S., \& Sonesson, I. (1991). TV in the socialization process. A study of preschool children in Sweden and Germany. Nordicom Review, 1, 15-23.

Jordan A., Kramer-Golinkoff E., \& Strasburger V. (2008). Do the media cause obesity and eating disorders? Adolescent Medicine: State of the Art Reviews, 19, (3), 431-449.

Krcmar, M., \& Vieira, E.T. (2005). Imitating life, imitating television: The effects of family and television models on children's moral reasoning. Communication Research, 32, (3), 267-294.

Lazar, B.A. (1994). Under the influence - an analysis of children's television regulation. Social Work, 39, (1), 67-74.

Livingstone, S., \& Haddon, L. (2009). Young people in the European digital media landscape. Gothenburg: Nordicom, University of Gothenburg.

Lowery, S. A., \& DeFleur, M. L. (1995). Milestones in mass communication research (3rd ed.). New York: Longman. 
Ma, G.S., Li, Y.P., Hu, X.Q., Ma, W.J., \& Wu, J. (2002). Effect of television viewing on pediatric obesity. Biomedical and Environmental Sciences, 15, (4), 291-297.

Martin, C.A., \& Benson, L. (1970). Parental perceptions of role of television in parent-child interaction. Journal of Marriage and the Family, 32, (3), 410-414.

Meirick, P.C., Sims, J.D., Gilchrist, E.S., \& Croucher, S.M. (2009). All the children are above average: Parents' perceptions of education and materialism as media effects on their own and other children. Mass Communication and Society, 12, (2), 217-237.

Mendelson, R.A., Dietz, W.H., Karp, S.K, Shelov, S.P., \& Stern, L.M. (1988). Commercialization of children's television and its effect on imaginative play. Pediatrics, 81, (6), 900-901.

Mosse, H.L. (1963). The influence of mass media on the mental health of children. Acta Paedopsychiatrica, 30, 103-111.

Murray, J.P. (2008). Media violence: The effects are both real and strong. American Behavioral Scientist, 51, (8), 1212-1230.

Möllerström. V., Sandberg. H., \& Ringsberg. K.C. (Red.). (2013). Medier och barns hälsa. Från peppning och glamour till trygg vägledning. En diskursanalys av två föräldramagasin (TemaNord 2013:501). Köpenhamn: Nordiska ministerrådet.

Nathanson, A.I., Wilson, B.J., McGee, J., \& Sebastian, M. (2002). Counteracting the effects of female stereotypes on television via active mediation. Journal of Communication, 52, (4), 922-937.

Nathanson, A.I., \& Yang, M.S. (2003). The effects of mediation content and form on Children's responses to violent television. Human Communication Research, 29, (1), 111-134.

Perloff, R.M. (1999). The third-person effect: A critical review and synthesis. Media Psychology, 1, (4), 353-378.

Pine, K.J., \& Nash, A. (2002). Dear Santa: The effects of television advertising on young children. International Journal of Behavioral Development, 26, (6), 529-539.

Ray, M., \& Jat, K.R. (2010). Effect of electronic media on children. Indian Pediatrics, 47, (7), 561-568.

Ringsberg K.C. (2013). Nordiska Livsstilsverkstan - En modell för intersektoriell samverkan mellan föräldrar, förskola, hälsoväsende och forskare. Slutrapport (TemaNord 2013:503). Köpenhamn: Nordiska ministerrådet. Rapporten är tillgänglig på www.norden.org

Ringsberg K.C. (2013). Nordiska Livsstilsverkstan - En modell för Intersektoriell samverkan mellan föräldrar, förskola, hälsoväsendet och forskare. Handledarguide (TemaNord 2013:504). Köpenhamn: Nordiska ministerrådet.

Roberts, C. (1981). Children's and parents' television viewing and perceptions of violence. Journalism Quarterly, 58, (4), 556-564.

Rucinski, D., \& Salmon, C. (1990). The "other" as the vulnerable voter: A study of the third person effect in the 1988 U.S. presidential campaign. International Journal of Public Opinion Research, 2, 345-368. 
Saelens, B.E., Sallis, J.F., Nader, P.R., Broyles, S.L., Berry, C.C., \& Taras, H.L. (2002). Home environmental influences on children's television watching from early to middle childhood. Journal of Developmental and Behavioral Pediatrics, 23, (3), 127-132.

Sandstig, G., \& Johansson, B. (2011). Media influences on preschool children's health and the role of the parent - A literature review. Paper presented at the NordMedia Conference 2011 Theory, Philosophy and Ethics of Communication, Akureyri, Iceland.

Sherry, J. L. (2001). The effects of violent video games on aggression - A metaanalysis. Human Communication Research, 27, (3), 409-431.

Shimai, S., Masuda, K., \& Kishimoto,Y. (1990). Influences of TV games on physical and psychological development of Japanese kindergarten children. Perceptual and Motor Skills, 70, (3), 771-776.

Strasburger, V.C., Jordan, A.B., \& Donnerstein, E. (2010). Health effects of media on children and adolescents. Pediatrics, 125, (4), 756-767.

Swinburn, B., \& Shelly, A. (2008). Effects of TV time and other sedentary pursuits. International Journal of Obesity, 32, 132-136.

Tsfati, Y., Ribak, R., \& Cohen, J. (2005). Rebelde way in Israel: Parental perceptions of television influence and monitoring of children's social and media activities. Mass Communication \& Society, 8, (1), 3-22.

Tufte, B., \& Ekström, K.M. (Eds.). (2007). Children, media and consumption. Gothenburg: Nordicom, University of Gothenburg.

Vastag, B. (2004). Does video game violence sow aggression? Studies probe effects of virtual violence on children. JAMA: Journal of the American Medical Association, 291,(15), 1822-1824.

Warren, R. (2003). Parental mediation of preschool children's television viewing. Journal of Broadcasting \& Electronic Media, 47, (3), 394-417.

Warren, R. (2005). Parental mediation of children's television viewing in lowincome families. Journal of Communication, 55, (4), 847-863.

Warren, R. (2001). Do as I say, not as I do: Video stores and parental mediation of children's video consumption. Mass Communication \& Society, 4, (1), 77-101.

von Feilitzen, C., \& Carlsson, U. (Eds.). (2007). In service of young people? Gothenburg: Nordicom, University of Gothenburg.

You, W., \& Nayga, R.M. (2005). Household fast food expenditures and children's television viewing: Can they really significantly influence children's dietary quality? Journal of Agricultural and Resource Economics, 30, (2), 302-314.

www.who.org

www.nhv.se 


\section{Summary}

The media is often the focus when children's health, and factors promoting health, are discussed. Too extensive television viewing, computer gaming and Internet use are often seen as harmful to children's health.

The purpose of this report was to conduct a literature review of empirical studies/previous literature reviews published in peer reviewed scientific journals. The selected articles analyzed media influence on pre-school children (3-5 years) focusing on: which aspects of children's health are influenced by the media, and how this influence can be explained? Which role do parents and the family play in the way media influence children's health?

An analysis of peer reviewed articles was carried out using the databases Social Science Citation Index (SSCI) in order to trace articles on the field of media and communication studies; the U.S: National Library of Public Health (PubMed) to find studies with health perspective and Nordicom Media Research Publications (Ncom) to locate the Nordic perspective. An additional search was performed using the Academic Search Elite (EBSCO), to come across studies unavailable in more field-specific databases.

The concepts - with corresponded meanings - used in the search were "media" and "influence" as well as "child" ,"parent" or "health" studying children in the ages 3-5 years (or parents with children in this age range). Totally 49 articles were included.

The analysis showed that the influence of the media on children's health, and explanatory models, could be compiled into four different themes:

- behaviour, moral reasoning and mental health

- weight, diet and physical activity

- advertising

- social and cognitive skills.

Pre-school children's health aspects predominately influenced by the media are aggression, obesity, development of social and cognitive skills and 
patterns of consumption. These effects can be found for both "traditional" /"older" types of media such as television and "new" like Internet and computer games.

Explanatory models used are primarily theories of social learning and imitation of behaviour. A strong correlation could be found between the amount of time pre-school children were exposed to media content and negative health consequences. Even sedentary activities, such as a television viewing, and its effects on time spent on other activities more favorable for developing a healthy lifestyle, were discussed.

Research on the role of parents and the family in the setting of media influence on children's health could be compiled in three different themes:

- resources of the family

- parental mediation

- attitudes and involvement of the parents.

The results found strong correlations between parents' extensive media consumption and a high level of media consumption of their children. Further, a low family income and a low education were related to increased television-viewing among all family members.

The empirical findings demonstrated also that parents can prevent their children from being exposed to harmful media content, by having negative attitudes toward media, media content and media influence. This effect can also be accomplished by combining these attitudes with a joint viewing or instructive mediation. The former mediation is more common in relation to pre-school children. A further finding was that the type of parental mediation used was more affected by media attitudes compared to the media use of the parents. Cultural resources are also seemed to be more important compared to material resources.

The literature showed that parents concern about negative effects on their own children, and opinions on effects on children in general, was related to parental mediation. However, the direction and magnitude of this relationship varies.

Future research should emphasize on parental mediation and toddlers related to socio-economic and cultural resources of families, this combined with attitudes and active behaviour of the parents. 


\section{Nordiska ministerrådet}

Ved Stranden 18

DK-1061 København K

www.norden.org

\section{Mediers påverkan}

Nordiska Livsstilsverkstan har utvecklats i ett projekt inom Globaliseringsinitiativet, finansierat av Nordiska Ministerrådet. Livsstilsverkstans huvudsyfte är att deltagarna skall skaffa sig kunskap om och förståelse av samband mellan livsstil och hälsa, hur det påverkar den egna, barnets och familjens hälsa samt att de reflekterar över hur man kan omsätta denna kunskap i praktiken. En förhoppning är att kunskapen skall föras över till barnen så att de i framtiden på egen hand kan göra hälsosamma livsstilsval. Arbetet i Nordiska Livsstilsverkstan bygger på samverkan mellan sektorer; familjen, förskolan, hälsoväsendet, barnavårdscentraler, familjecentraler och forskare.

Det är viktigt att människor har kunskap om hur man skall tolka de budskap som medier för fram. Denna rapport är en litteraturstudie och omfattar analys av fyrtionio empiriska studier och litteraturstudier presenterade i vetenskapligt granskade artiklar som undersökt mediers påverkan på förskolebarns hälsa (3-5 år). 